\title{
The Role of Coal-Mining Museum in Kuzbass Coal Industry Development
}

\author{
Dmitry Kuznetsov ${ }^{1}$, Anna Novoklinova $^{1}$, Nadezda Rabkina ${ }^{1,}{ }^{*}$, and Olga Valko \\ ${ }^{1}$ Kemerovo State University, 650000, 6 Krasnaya St., Kemerovo, Russia
}

\begin{abstract}
A museum cluster is a phenomenon that did not acquire conceptual understanding until the late 1990s. Since then, numerous approaches to defining a museum cluster have been put to the test. It has been unanimously stated that a museum cluster is an environment-creating and culture-forming entity, which catches the spirit of the time/place and embodies the locus genii. The museum, thus, renews and strengthens itself in the urban, scientific and cultural thought. These apply well to Krasnaya Gorka, a museum cluster in Kemerovskaya oblast. Combining all 'cluster' characteristics, Krasnaya Gorka features very specific, historically and culturally valuable trends eventually transforming the urban environment and forming local traditions. The study is aimed at comprehensive research of a museum cluster contribution to the local culture, environment, science, economy and, most importantly, people. The study showed that: (1) the Krasnaya Gorka museum is justifiably the heart of a cluster; (2) the archival materials in city museums are valuable as integral historic documents in their own right, but more significant when regarded along with other papers and artefacts in the domain of the museums, forming the cluster; c) the Krasnaya Gorka museum is a culture-forming entity due to its aggregating people and organizing activities.
\end{abstract}

\section{Introduction}

Having experienced an unprecedental boom, the museum established itself as a tourist magnet, an architectural manifesto, and a symbol of the postmodern city and culture. In this culture, the museum occupies a privileged place within the city environment both physically and spiritually. It takes on educational and cultural commitments. Moreover, it creates the environment, defines it, changes it and gives it a specific meaning. All above mentioned in the concentrated and optimized form can be found in the museum cluster [1].

Kemerovskaya oblast is a typical resource region whose economy hinges on exportoriented heavy industries. At the same time, the region possesses a significant touristic potential. It is only logical that local tourism should be developed on the basis of existing historical and natural recourses, which would be much more cost-efficient. Such an approach makes tourism a catalyst of the regional economy [2].

\footnotetext{
${ }^{*}$ Corresponding author: nrabkina@mail.ru
} 
The Krasnaya Gorka, or Red Hill, open-air museum, serves a model to follow for other regions planning to set up an industrial museum complex [3]. It is a part of the Golden Ring of Kuzbass project [4].

According to the museum authorities, the cluster should be integrated in relevant social processes by preserving the industrial heritage, encouraging scientific research, using various media to promote local history, educate young visitors, raise their patriotism, and increase the prestige of mining professions, and introduce new form of cultural entertainment. Its ultimate goal is giving a new life to the historical city district while preserving the good traditions shared by its community and, finally, creating a new museum complex of global significance that will boost local tourism and give new jobs [5-6].

\section{Materials and methods}

We maintain that the cultural objects in Kuzbass region or, specifically, the capital city of Kemerovo, bear the most characteristic features of a cluster-forming entity, namely: cultural integrity, locality uniformity, time/space originality and (approximate) origination simultaneity, and tourist attendance. Therefore, in evaluating the cluster-forming situation, the following methods are of primary use: a) collecting and sorting data with reference to all cultural objects on site; b) establishing the existing links between the objects mentioned; c) analyzing the cultural value of the contents collected in the archives and their intercrossspecificity; d) estimating the tourist flow from one object to the other.

With all these in view, it is essential to carry out the following tasks: a) to analyze the historic data kept in the cluster's archives; b) to look into the matters of cultural and experience tourism, focusing on the attractions that seem to be the most interesting to potential visitors (and most lucrative for the cluster itself); c) to define, what really can make a museum cluster like Krasnaya Gorka a locus genii.

\section{Results and Discussion}

\subsection{Overall status of the Krasnaya Gorka museum}

Museums and museum projects carry out various functions, the most important of which are obviously storing and exhibiting artifacts of different kinds. Thus, the urbanistic aspect of the museum, i.e. its place and relationship with the city and the citizens (permanent or temporary), may seem less important than the museum collections and funds. Surprising though it may seem, at the moment the urbanistic aspect of the museum takes precedence over its museographic and architectonic aspect. The content and architecture of the museum merge into the cultural density of the cluster, foregrounding the place and urbanism of the museum [7-8].

Founded in 1991 to preserve the historical center of Kemerovo, the Krasnaya Gorka museum is relatively young. For nearly 16 years there was only one scheduled monument on the territory of the museum - the Obelisk commemorating the discovery of Kuznetsk coal in 1721. It was erected in 1960 as a monument of federal significance.

In 2006, the regional authorities passed a local law on cultural heritage of Kemerovskaya oblast, which gave museum workers an opportunity to schedule other 14 buildings as monuments of regional value. According to specialists in architecture, the Krasnaya Gorka museum can be considered a complex of historical and cultural, as well as landscape and architectural significance. Its objects are unique; they maintain their authentic look, which makes them important from the aspect of historical city-planning. 
The historical sites of the Krasnaya Gorka cave a great resource potential, which makes them a factor of economic and social development of the city [9].

Nowadays, the historical monuments of the Krasnaya Gorka museum can be divided into several categories basing on the time factor:

- Monuments related to the earliest period of industrial development. There is the natural monument of the Krasnaya Gorka itself, where the first coal was discovered in 1721, and the blocked entry of one of the first river-side shafts dated 1907.

Sites related to the Kopikuz joint-stock company (1915-1917). They are scattered all over both banks of the river Tom and include the stone jetty with an ice-breaker, the cable-road tower, the arched coal-preparation building of the coking plant, the first stone building in the city, where the Kopikuz CEO used to live and where the museum is headquartered now, and the head office of the Kemerovo mine, which is currently closed and not available for visiting;

- Buildings of the last period of the Autonomous Industrial Colony (AIC) Kuzbass (19251927). This legacy involves the surviving buildings designed by Dutch architect Johannes Van Loghem in 1926-1927. Perhaps, the most impressive of them is the double-winged school with a water tower in the middle. The school looks alien to Russian architecture, but it corresponds to the main principles of functional architecture. It used to be a very comfortable building full of light and air. Then come the terraced one-storeyed houses for ordinary workers and their families, whose analogues can be found among best Van Loghem's social projects in the Netherlands. Their unusual facades made local people call them "sausages". Another Van Loghem's heritage is the so-called houses for the "spets" (specialists), the two-storeyed buildings for two or four families, which he designed for engineers. These were built according to several patterns and introduced some very novel building techniques - too novel, perhaps, since the Gerard masonry was highly ridiculed by the locals at that time. However, while the sausage-houses and the school now stand empty and closed for public, these town-houses are still inhabited and considered somewhat elite living quarters. Their red roofs, together with that of the museum and the red burning heart of the coal-miners' memorial, visually make up a single complex that can be seen from the promenade on the opposite bank. Finally, there is the bathhouse made of reinforced concrete, which was constructed by an American AIC architect. Now it is in private property and hosts a bathhouse and a garage;

- Modern monuments. They include the Obelisk of 1960, the memorial designed by Ernst Neizvestny (2003), the Horse Driver sculpture (2008) and the monument of St. Varvara (Barbara), the patron saint of coal miners.

Besides, the museum possesses a rather big open-air territory with information billboards, an impressive display of authentic mining equipment and a viewing platform looking onto the city center, the new bridge, the industrial landscape of the coking plant and the power station.

The role of the museum and particularly the museum cluster is exceedingly important. They catch and condense the spirit - the spirit of the time, the spirit of the place and the spirit of knowledge and culture. By mounting exhibitions and displaying their funds, museums make this spirit visible and tangible, spread it throughout the city, transform the urban environment into their integral part, the space of enlargement and amplification. Embodying and materializing the locus genii, the museum persists, renews and strengthens itself in the urban, scientific and cultural thought [1].

\subsection{Scientific role}


The Russian Scientific Net www.e-library.com contains a number of scientific papers that feature the Krasnaya Gorka museum. Their analysis helps classify them thematically into these groups:

- historical publications that cover history of coal exploration, industrial and urban development, industrial heritage, World War II, and the Autonomous Industrial Colony Kuzbass, etc.;

- publications on the international aspects of culture, i.e. issues of the Dutch architectural heritage, its preservation and reconstruction, history and current state of Kuzbass-Dutch affair, etc.;

- publications on touristic potential of the region (historical and industrial tourism);

- museum-related publications reviewing various aspects of museum work, e.g. hi-tech in museum environment, personnel management, charity events in museums, museum archives, museumification of the area, the role of the museum in the image formation of the region, museum as a base for educational programs, field practice, etc.

The aspects enumerated above set down the principal directions of scientific research concerning the museum infrastructure of the region and identify the apical points for the sector.

\subsection{Archives}

The museum treasures vast archives of documents on the history of coal industry in Kuzbass, some of them in English and Dutch. The list includes memoirs, diaries and correspondence of colonists, their biographies, AIC-related newspaper clippings, and foreign studies in the history of the AIC Kuzbass, Dutch architecture, etc. Their translations regularly appear in the issues of The Krasnaya Gorka Almanac. They also contain some fiction, the major samples of which are the following:

- "Een Beetje Vrijheid" (A Bit of Freedom) by Tini Schoorl-Straub, a Dutch colonist, public activist and journalist. The book summarizes the author's Siberian experience. In spite of changing names for all real characters, a specialist in Kuzbass history will clearly see who is who in her novel. Thus, the book serves a documentary source and an object of careful study;

- "Comrade One Crutch" by Ruth Kennell, an American colonist, feminist and writer, much more prolific in her oeuvre. She produced a number of novels and stories for children about Siberia and the Soviet Russia. "Comrade One Crutch" was adapted for the Kemerovo Theatre of Young Audiences, thus extending the Krasnaya Gorka cultural environment into other spheres of mass culture.

The museum accumulates new information that is currently published in Russian and foreign sources - monographs, researches on family genealogy, mass media articles, etc.

\subsection{Community}

The sector of tourism is going through a transformational period caused not only by technical advancement but also by customers' changing tastes and expectations. So far, the prominence is given to a more traditional cultural tourism and a more innovative experience tourism. "Cultural tourism has been identified as a growing sector of the tourism industry" [10]. As the demand for cultural tourism has grown, museums have become important partners in the tourist industry, and greater emphasis is now being placed on their leisure function [11]. With their unique features, rich connotations, flexible open hours, multiple exhibition facilities, shops and restaurants, museums are ideally placed to satisfy a range of consumer needs. The notion of experience tourism is harder to define. The main aim is to gain tourist experience that may include various components or constituents providing 
physical, emotional, intellectual, and even spiritual fulfilment. That definitely implies more active practices for tourists, which turns to advantage for local museum visitors.

The museum turns into a base for community meetings bringing together active citizens and the city authorities. The museum encourages people to share their personal narrative to make a patchwork of local history. For instance, museum personnel collected memories of World War II and family photos depicting local urban history. There is an annual donator's day when the museum honors residents who have donated historically significant items. Donators and their family members are always welcome free of charge. Indeed, items donated by Kemerovites inspire temporary expositions: old cuckoo clocks, Soviet school items, postcards, etc.

Culture has become a key factor in the competition among cities to attract visitors, and an important part of the service-based economy [7]. Thus, the museum has quite a busy yearly schedule and uses every opportunity to bring people together. There are various events arranged for various public holidays: piano concerts for the New Year's Day, charity events for Christmas, special meetings for the Victory Day, dances on the Family Day, etc. On the Defender's Day (February 23) a man with a military ID can take his family to the museum free of charge. The museum tries to set up new trends, such as the Ramson Day, when visitors are told about popular dishes made of ramson, or bear's onion (Allium ursinum).

On the city Day the museum opens its doors to wedding ceremonies. Besides, the newly-weds are allowed to light a fire in the oldest fireplace in the city. This symbolic act, together with a photo session, has become very popular with the city dwellers.

The museum opens its doors to special categories of visitors, e.g. wheel chair users, senior citizens. The museum hosts charity events for orphanages, children with TB, etc. The traditional Kind Christmas Tree campaign gives visitors and active citizens an opportunity to donate toys, books, and other necessary things [6].

The museum cluster clearly manifests changes in the city, culture and society, which makes it a privileged position to analyze the changes in the concept of the museum as an institution, as an architectural design and, above all, as an urban pattern, and thus to consider the relationship between culture and ideology in the structure of the city.

Multiple functions which the museum and its cluster have in the city and society place it simultaneously on two tracks - in the centre of the ideal and symbolic schemes, as the bearer of the idea of locus genii [12] which generates the city and its spirit.

\subsection{Expansion abroad}

The museum maintains connections with other cultural institutions abroad. For instance, it shares common interest in Functional architecture with the museum Het Schip in Amsterdam. During the year of Russian and Dutch Culture in 2013, the museums opened exhibitions dedicated to Johannes Van Loghem, a Dutch architect that worked in the Autonomous Industrial Colony Kuzbass in 1926-1927. This outstanding historical character still interests researchers in various fields. In 2014 Dutch Architectural Society ordered a film about his oeuvre, which is, unfortunately, still in progress. In 2017, The International Institute of Social History in the Netherlands made a film based on Van Loghem's correspondence with his wife: the film was compiled from archival photos and shot sequences. "Bouwen te Midden van Eenzaamheid" (Building amidst Solitude) by Pim Zwir was dubbed in Russian and demonstrated in the museum [13].

\subsection{Virtual landscape}


Museums, as cultural institutions, have become the catalysts of city development and boosted the power of local economies. D. Fleming described museums as 'defibrillators', adding that, whatever their social value, museums act as an economic improver [14].

The museum not only preserves its area, but also generates virtual environment. One of its exhibition halls permanently hosts an exhibition devoted to the Kemerovo that never was or the Kemerovo that will never be: city plans and sketches of buildings that never came to life, toponyms that were not accepted, landscapes of the past consumed by modern urban environment, etc. Posters on the outlook platform compare views of modern and past state of popular city locations, thus merging various time layers [15].

The real historical environment of the Krasnaya Gorka is undergoing gamification. A group of young enthusiasts obtained a grant from the local government to create a monopoly-type table game called "The Burnt Hill". It features real historical characters and represents the history of coal discovery and industrial development of the region.

The site of the museum is a good source of historical information. Besides, the museum with its public events often makes headlines of local TV and Internet news.

Museums work with the tourist industry in a number of ways: by launching cooperative ventures with other cultural institutions, leisure venues and districts, and by supporting local festivals. From the economic viewpoint, museums are cultural products that attract tourists.

\section{Summary}

The Krasnaya Gorka museum is not a historic/cultural location in itself. It is the core of a grand coal-mining history cluster, aggregating various city locations with their own programs and plans, contents and agenda, plethora of visitors and specificities.

Moreover, the tourist attraction venue naturally starts with the Krasnaya Gorka, further expanding to the less famous or popular sites of the city, thus making them subsidiaries to the grand name, primarily associated with coal-mining industry.

One of the other aspects that cannot be ignored is the educational value of the cluster. Numerous collective visits, organized on a regular basis, enlighten the young about the history of the region and its industrial feats, mostly associated with coal-mining. The same ideas are promoted further on during the subsequent visits to other local museums and sights, which naturally expand the visitors' awareness of the core-forming significance of the mining industry in the region.

For visitors (as well as the locals) the cluster acquires the status not only that of loci genii, but of the locus sine qua non, that is to say, 'a place one MUST see'.

Logically, it is the industry itself that gives worth and weight to the power of the cluster. The cluster represents industry as much as the industry is cluster-bound.

\section{References}

1. V. Nikolić, Tourbanism, 25, 00101 (2012)

2. O. Brel, Ph. Kaiser, Bulletin of Kemerovo State University, 3, 25-28 (2017)

3. E.V. Kulagina, Yu.V. Slivkova, Almanach of Modern Science and Education. 11:113, 74-77 (2016).

4. V.M. Kimeev, Studies and Preservation of the Cultural Heritage of the Altai Krai, (KemSU, Kemerovo, 2016)

5. N.A. Shelepova, Z.F. Volkova, A.V. Deryushev, Proceedings of XV International Scientific and Practical Conference, 9, 9-11 (2013) 
6. N.A. Shelepova, A.F. Pokrovskaya, A.I. Zhukova, Notes of the Open-Air Museum Tomskaya Pisanitsa, 3, 5-18 (2016)

7. M. E. Porter, Harvard Business Review, 11, 77-90 (1998)

8. F. Mairesse, Séminaire: Les musées du Quartier du Mont des Arts, Musées royaux des Beaux-Arts à Bruxelles, 19 mai 2000. Série: Le Mont des Arts, 14-15 (Fondation Roi Baudouin, Bruxelles: 2000)

9. I. V. Zakharova, Bulletin of Kuzbass State Techtical University, 01, 162-166 (2010)

10. B. Lord, Cultural Tourism and Museums. (LORD Cultural Resources Planning \& Management Inc., London, 2002)

11. A. Stephen, Museum Management and Curatorship, 19:3, 297-308 (2001)

12. V. M. Welter, Modernism and the Spirit of the City (Routledge, London, 2003)

13. Bouwen te midden van eenzaamheid. Building amidst solitude (NDTE, Amsterdam, 2017)

14. D. Fleming, INTERCOM 2006 Annual Meeting and Conference (INTERCOM, Taipei, 2006)

15. J. A. Agnew, J. S. Duncan, The power of place: bringing together geographical and sociological imaginations (Unwin, Hyman, 1989)

16. T. F. Gieryn, Annual Review of Sociology, 26, 463-496 (2000) 